\title{
Moderating Effect of Organizational Culture on the Relationship between Organizational Learning and Employees' Performance in Classified Hospitality Firms in Kenya
}

\author{
Njoroge Paul Thumbi ${ }^{1}$, Bula Hannah ${ }^{1} \&$ Wanyoike Rosemarie ${ }^{1}$ \\ ${ }^{1}$ School of Business, Kenyatta University, Nairobi, Kenya \\ Correspondence: Njoroge Paul Thumbi, School of Business, Kenyatta University, Nairobi, Kenya. E-mail: \\ paultnjoroge@gmail.com
}

Received: September 5, 2020

Accepted: October 13, 2020

Online Published: November 6, 2020

doi:10.5539/ijbm.v15n12p51

URL: https://doi.org/10.5539/ijbm.v15n12p51

\begin{abstract}
Empirical literature reveals that organizational culture has a pervading influence on organizational processes, strategies, systems and outcomes. However, there is need to establish the nature of this influence at employee level. The purpose of this study was to examine whether organizational culture moderates the relationship between organizational learning and employees' performance. Data was collected using a self-administered questionnaire from a sample of 225 respondents drawn from 75 classified hospitality firms in Kenya. Data was analyzed using multiple regression analysis to examine the empirical models. The results established that organizational culture significantly moderated the relationship between organizational learning and employees' performance. The findings revealed a strong relationship between organizational learning and employees' performance for firms that are higher in people orientation.
\end{abstract}

Keywords: Employees' performance, organizational culture, organizational learning

\section{Introduction}

An organization is described as a social and physical construction which is shaped by its own culture (Hogan \& Coote, 2014). This assertion is emphasized by empirical studies that show that organizational culture significantly affects organization's behaviour and performance (Hogan \& Coote, 2014), employees' performance (Emeka \& Philemon, 2012) and organizational learning (Zheng, Yang, \& McLean, 2010). Bandura (2006) postulates that learning comprises social dimensions whose elements and measures are influenced by the context. However, cultures vary from one organization to another and from one social context to another (Afaneh, Khaireddin, Sanjuq, \& Qaddoumi, 2014).

Employees' performance and organizational learning are products of contextual elements in the organization (Isa, Ugheoke \& Noor, 2016). Empirical literature has drawn a link between organizational learning and employees' performance with evidence that organizational learning aligns employees to organizational goals and values and improves their citizenship behaviour. Further, organizational learning is linked to employee's attitudes, perceptions and actual behaviour (Zhang \& Li, 2009; Lee \& Huang, 2012). Employees are at the heart of organizational learning and performance as firms are reliant on employee's creativity, innovativeness, exploitation existing and new knowledge, and skills sharing (Jong \& Hartog, 2007).

Although it is acknowledged that through organizational learning practices firms can optimize knowledge resources for improved performance at firm and individual levels, there exists obstacles to achieving optimal performance (Gomes \& Wojahn, 2016). The main barriers to achieving optimal employees' performance is attributed to unsupportive organizational cultures such as lack of learning culture, lack of management support and inadequate employee welfare programs (Bilgihan \& Nejad, 2015). This shows the significance of organizational culture in creating a context that stimulate learning and performance. Firms should nurture a culture that promotes personal creativity, enhance sharing of knowledge and effectively acquire relevant knowledge on new trends and best practices in the industry (Zaitseva, 2013).

Despite the consensus that organizational culture shapes organization stature, there is limited empirical studies that focus on the moderator role of organizational culture on organizational learning and employee's performance. This echoes the argument that that the moderating factors influencing the organizational learning and employee's 
performance have not been exhausted (Lian, Yang \& Ma, 2013). Similarly, Gomes and Wojahn (2016) have called for future research to adopt different conceptual models in order to broaden and deepen the state of literature.

The bulk of studies on organizational learning and employees' performance have been conducted in the Asia and Europe, contexts which limit the generalization of the findings to the developing world since organizational learning and employee performance are influenced by the contexts the firm operates in (Ajayi, et al., 2016). This points to a contextual gap in extant literature. Caniëls and Veld (2016) calls for research that considers the contextual effects of industry diversity. In response to this call, this study focused on the classified hospitality firms in Kenya.

The general objective of this study was to examine the moderating effect of organizational culture on the relationship between organizational learning and employees' performance in classified hospitality firms in Kenya.

The specific objectives of this study are:

i) To establish the relationship between organizational learning on employees' performance in classified hospitality firms in Kenya

ii) To examine the effect of organizational learning on employees' performance in classified hospitality firms in Kenya

iii) To determine the moderating effect of organizational culture on organizational learning and employees' performance in classified hospitality firms in Kenya.

The research hypotheses for this study are stated in the null hypothesis as follows:

$\mathrm{Ho}_{1:}$ There is no relationship between organizational learning and employees' performance in classified hospitality firms in Kenya

$\mathrm{Ho}_{2}$ : Organizational learning has no effect on employees' performance in classified hospitality firms in Kenya

$\mathrm{Ho}_{3}$ : Organizational culture has no moderating effect on organizational learning and employees' performance in classified hospitality firms in Kenya.

\section{Literature Review}

\subsection{Organizational Culture}

The concept of organizational culture has over the years received varied descriptions with scholars proposing different dimensions and typologies of studying organization culture. Schein's (1992) model conceptualizes organizational culture as the shared values communicated through norms and observed in behavioural patterns. Schein's model categorizes organizational culture into three levels comprising artifacts which comprise the visual organizational structures and process which are hard to understand or decipher yet they are easily discerned; espoused values constituting strategies and goals; and the basic assumptions comprising beliefs, perceptions, thoughts and feelings, all of which are difficult to discern.

According to Hofstede (1997), organizational culture elements include symbols, heroes, rituals and values and the five dimensions of organizational culture which influence the behaviour in the organization as power distance, masculinity versus femininity, individualism versus collectivism, uncertainty avoidance, and long-term orientation. The model indicates that an organization's value system influences decision making, search for knowledge and interpretation of information. On the other hand, norms are social expectations which are based on the underlying values and represent the guidelines on behaviour expectations, with clear sanctions and correction (Hogan \& Coote, 2014). On the hand, the competing value framework (CVF) classifies organizational culture into clan, adhocracy, market, and hierarchy dimensions (Quinn \& Robert 2011). The clan culture is characterized by knowledge sharing, adhocracy culture by self-motivation, entrepreneurship and innovation, market culture by a climate of competition, and hierarchical culture by an unambiguous structure, formal policy and procedures, strict control, and clear responsibilities (Tseng, 2010).

Robbins (2003) advances several factors that determine the unique culture of every organization. These factors include innovation, risk taking, leadership, integration, management support, control, identity, reward system, compromise with conflicts, and communication patterns. These characteristics are identified as measures of a firm's culture. Robbins and Judge (2013) provide a holistic view of organizational culture in a framework that identifies seven characteristics that fundamentally describes organizational culture. These characteristics include innovation and risk taking, attention to detail, outcome orientation, people orientation, team orientation, aggressiveness, and stability.

The dimensions of innovation and risk taking, outcome orientation and people orientation are adopted to 
conceptualize organizational culture. Innovation and risk taking involve the extent to which the firm values and supports generation and implementation of new ideas, outcome orientation entail the extent to which the organization focuses on results and goal attainment, and people orientation focuses on employee's fairness, support and rights.

\subsection{Organizational Learning}

The perspectives of organizational learning advanced by various scholars are distinct in their operationalization of the concept. For instance, Argyris and Schön (1996) views organizational learning as a cognitivist action in which focus is placed on mental models of learning and subjugates practical aspects of learning. This view is shared by Bandura (1997). On the contrary, Daft and Weick (1995) view organizations as interpretative systems and learning is conducted through a three-phased model of data collection, data analysis and interpretation and application. Senge (1990) asserts that organizational learning begins with individuals who learn. This premise places employees, individually and collectively, at the heart of organizational learning. Senge (1996) proposes a fivedimensional model of organizational learning comprising personal mastery, mental models, shared visions, teamlearning, and systems thinking encapsulating learning at individual, group and organizational levels.

Huber's (1991) viewed organizational learning as a process comprising acquisition of knowledge, distribution and interpretation of information, and organizational memory. Sanchez, et al. (2010) adopting this model, emphasized that the process approach incorporates the fundamental aspects of organizational learning. From this theoretical background scholars have aligned their studies with differing theoretical positioning which has given rise to varied conceptualization of the organizational learning. Some scholars have studied organizational learning as a capability (Chiva, et al., 2007; Lin, 2008; Gelard \& Mirsalehi, 2010), others have studied the concept as a process (Argote, 2011) and still others have viewed it as culture (Hua \& Chan, 2013). For the purpose of this study, Huber (1991) model of organizational learning was adapted.

The constructs of organizational learning used in this study were knowledge acquisition, information distribution, information interpretation and organizational memory as used by Sánchez, et al., (2010). Knowledge acquisition is indicated by founder's vision or congenital learning, experience-based and indirect learning, searching and grafting. The second construct information distribution is indicated by meetings, communication, cross-training, discussions and proposals, social networks, and information diffusion. The third construct information interpretation is measured in terms of interpretation frameworks, media, information overload, promptness, and unlearning processes. Finally, organizational memory is measured in terms of specialists or experts, training programs, skills and abilities database, and knowledge access

\subsection{Ability, Motivation and Opportunity Theory}

Ability, motivation and opportunity (AMO) theory advanced by Appelbaum, et al, (2000) has become a fundamental theory in HRM literature. The theory proposes that the firm's performance is a product of employee outcomes highlighted by employee attitudes, motivation and opportunity to perform and contribute to organizational goals. The theory postulates that it is the employee's attitudes and resultant behaviour or performance that directly influence how organizations systems impacts firm performance. This view holds that employee performance is the fulcrum of the firm's performance (Zhang, et al. 2014). Organization's culture and climate characterized by HR strategies, policies, systems and practices should focus on enhancing employee performance through developing employees' abilities and motivation to perform and creating opportunities for them to make significant contributions to organizational goals (Katou \& Budhwar, 2010).

According to Macky and Boxall (2007), employee's ability determines the extent of performance, motivation of employees influences the extent to which the employee exert themselves within their abilities, and opportunity involves the chances the ability of the motivated employees to immerse themselves to perform as per the requirements of their roles and standards of performance set. Kang and Snell (2009) draw the link between organizational learning and employee's performance through maximization of intellectual capital. Employees whose abilities have been enhanced, are motivated, and provided opportunities for growth are more likely to be creative, optimize and share knowledge, seek new knowledge and ultimately be more inclined towards the performance goals of the organization (Perez \& Pastor, 2013).

\subsection{Task and Contextual Performance Model}

Task and contextual performance model by Borman and Motowidlo (1993) has been embraced by scholars. The model view task performance as employee's effectiveness in executing technical activities while contextual performance refers to employee's undertaking of activities that relate to social, cultural and psychological contexts or dimensions of the organization. The contextual performance dimensions comprise enthusiasm, extra effort, 
volunteering, assisting and cooperating with coworkers, adhering to rules and procedures and participating in corporate affairs (Borman \& Motowidlo, 1993).

Dhammika (2013) tested the validity of the task and contextual model of performance and found that measures such as task execution, job proficiency, efficiency, assisting coworkers, cooperation, and teamwork were valid measures of employee's performance. Contextual performance closely relates to organizational citizenship behaviour which comprise elements of altruism, courtesy, sportsmanship, conscientiousness and civic virtue. Of interest to this study is altruism which refers to employees' activities of helping and assisting colleagues, conscientiousness which involves adherence to the rules and regulations, and civic virtue which is demonstrated in employee's concern and interest in the affairs of the organization. This study adopted task and contextual model to measure employee's performance. The indicators of employees' performance, therefore, include service delivery, efficiency, teamwork, and citizenship behaviour.

\subsection{Organizational Learning and Employees' Performance}

Several studies have sought to establish the link between organizational learning constructs and employees' performance. For instance, Akpotu and Lebari (2014) investigated the relationship between knowledge acquisition and employee's performance in tertiary educational institutions in Nigeria. The study adopted survey design in which representative sample was selected using random sampling method and data analyzed using regression model specification. The results showed that knowledge acquisition has significant effect on employee's performance.

Richards and Duxbury (2014) investigated the determinants of knowledge acquisition in public-sector organizations. A sample of 179 respondents was selected using stratified random sampling and data was analyzed multi-level regression. The findings revealed that contextual factors influence acquisition of knowledge with management playing a critical role. The management role is primarily in searching for new knowledge from external sources and grafting or appropriation of this knowledge into the organization.

Empirical studies reveal that the transfer or distribution of knowledge within work groups and among different organizational units is fundamental to organizational learning. A study by Argote and Spektor (2011) draw a link between organizational learning and performance. The study posits that information distribution and knowledge dissemination involves organizing, capturing and actual distribution of knowledge and information to other users. Employees learn directly from own experience and indirectly from other each other. Although it is difficult to disseminate and formalize tacit knowledge, it creates inimitability which is a basis for competitive advantage. Information distribution across groups, organizational units or geographical boundaries done through technology, personal movement, templates, routines and social networks and alliances mechanisms.

Fletcher and Prashanthan (2011) examined knowledge assimilation process of rapidly internationalizing SMEs. The study adopted a qualitative enquiry using four selected cases and focus groups. The results establish that transfer or distribution of knowledge within work groups and among different organizational units is fundamental to organizational learning. This distribution occurs in a shared social context of interlinked units through a network of shared resources. To facilitate knowledge and information distribution across work groups and organizational units, line managers play a critical role as the pillars of dissemination through provision of managerial support.

Ekore (2014) investigated the impact of key organizational factors on knowledge transfer in multi-national firms in Nigeria. A sample size of 125 employees from two multinationals were randomly selected for the survey. The collected data was analyzed using multiple regression analysis. The study sought to establish whether that organizational factors including culture, strategy, information technology, training and organizational performance significantly influence transfer and distribution of knowledge and information. The findings showed that apart from training the rest of organizational components do not have significant influence.

Torabi, Kyani and Alakinia (2016) investigated the effect of information interpretation on human resource performance in banking sector in Tehran. The study adopted survey design in which a sample of 21 respondents were surveyed. One sample t-tests and Chi-square statistics were used to test hypotheses. The findings revealed a correlation between knowledge and information interpretation and human resource performance. In particular, the results show that effect of information interpretation mainly influences employee ability to perform their tasks.

Dunham (2011) examined the link between organizational memory and employee empowerment. The study sampled 134 employees drawn from six companies in New Zealand and data was analyzed using hierarchical regression analysis. The findings reveal a significant relationship between organizational memory and employee empowerment and organizational based self-esteem. Organizational memory had great impact on employee outcomes. 


\subsection{Moderator Role of Organizational Culture}

Nazir and Zamir (2015) examined the influence of organization culture on employees' performance in Islamabad. A sample of sixty employees was selected from diverse organizations. Descriptive statistics and inferential statistics including t-tests and Pearson correlation were used to test hypotheses. The findings indicate that organizational culture affects the contextual environment of employee performance. The study shows that organizational culture manifests in form of subcultures constituting different sets of norms, values and beliefs which are determined by job necessities and organizational goals. The study further revealed that values and norms affect realization of organizational goals and performance as they influence behaviour expectations of employees.

Afaneh, et al. (2014) sought to establish the effect of organizational culture on organizational commitment in Jordanian Private Universities. A questionnaire was developed and distributed to a sample of 182 respondents comprising middle-level managers. Inferential statistics including t-tests and regression analysis were used to analyze and test hypothesis. The findings show a statistically significant impact of collective cultural dimensions on organizational commitment and employee behavioural performance.

Emeka and Philemon (2012) conducted a study on the effect of organizational culture on employee's performance in selected manufacturing firms in Nigeria. The study used survey design in which manufacturing firms were selected using stratified random sampling and the respondents through simple random sampling technique. Analysis of data was done using both descriptive and inferential statistics; in particular, measures of central tendency and Chi-Square. The study established a positive relationship between organizational culture and employee performance and organizational productivity. The results emphasized that values and norms define performance expectations and measurement.

Erkutlu (2011) examined the moderating effect of organizational culture on the relationship between citizenship behaviour and justice perceptions in Turkey. Data was collected from 618 respondents randomly selected from ten universities in Turkey. Using a multilevel research design, multiple hierarchical regressions results revealed that organizational culture dimensions of team orientation and respect for people had moderating effect on the linkage between citizenship behaviour and justice perceptions.

\subsection{Conceptual Framework}

Independent Variable Dependent Variable

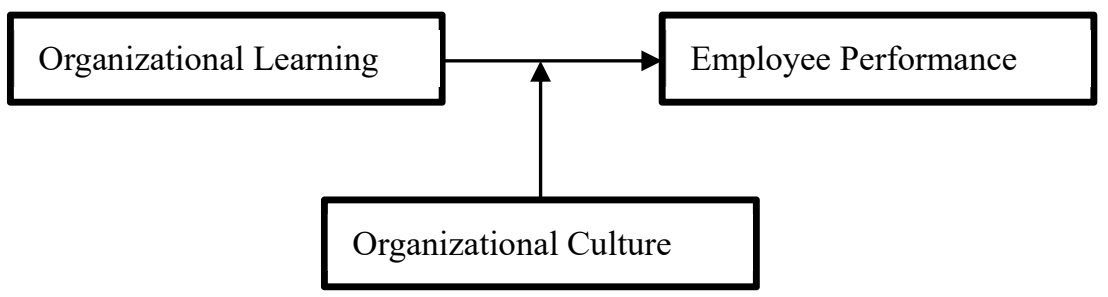

Moderating Variable

Figure 1. Conceptual Framework

Source: Njoroge, Bula and Wanyoike (2020).

\section{Research Methodology}

\subsection{Method}

Both descriptive and explanatory research designs were adopted for the study. The designs were cross-sectional in nature. The target population comprised 75 firms classified as five-star, four-star and three-star which were selected using purposive sampling method. This population constitute $38 \%$ of the total classified hospitality firms in Kenya. Using stratified random sampling, a proportionate number of respondents were selected from each category. A sample of 225 respondents comprising managers for human resources, food and beverage, and accommodation and conferencing was selected. Data was collected using a semi structured self-administered questionnaire which was delivered to each manager.

To ascertain criterion-related validity, the researcher adapted measures that have been validated in previous studies. 
Organizational learning was measured using the Huber (1991) model. The twelve-items scale used in each construct (Knowledge acquisition, information distribution, information interpretation and organizational memory) were adapted from Huber (1991) model validated by Sanchez, et al. (2010). Organizational culture was studied using a nine-item scale adapted from Robbins and Judge (2013) model. Employees' performance was operationalized using a twelve-item scale adapted from Borman and Motowidlo (1993) task and contextual model whose measures were validated by Dhammika (2013). To test the reliability of the quantitative measures, Cronbach's Alpha Coefficient statistical method was used in which a Cronbach's alpha coefficient value greater than 0.7 was considered adequate.

The empirical model for relationship between organizational learning and employees' performance was moderated by organizational culture. The relationship between the study variables were determined using regression analysis. The moderation effect of organizational culture on the relationship between organizational learning and employees' performance was tested using Whisman and McClelland's (2005) two-step model. The moderation effect was tested by determining whether the coefficient of the interaction term was statistically different from zero. Pearson correlation analysis was used to evaluate whether there was statistical evidence for a linear relationship among the same pairs of study variables. The correlations were to be considered strong if the coefficient $r>0.5$ at $95 \%$ level of confidence (Saunders, et al., 2012).

\subsection{Measurement of Variables}

Organizational culture, the moderating variable, was operationalized using Robbins and Judge (2013) dimensions of innovation and risk taking, outcome orientation and people orientation to conceptualize organizational culture. Innovation and risk taking involved the extent to which the firm values and supports generation and implementation of new ideas, outcome orientation entailed the extent to which the organization focuses on results and goal attainment, and people orientation focused on management value of fairness, supportiveness and respect for individual rights.

The constructs of organizational learning were adapted from the seminal work of Huber (1991) as advanced by Sanchez, et al. (2010). The constructs which formed the explanatory variables were knowledge acquisition, information distribution, information interpretation and organizational memory. The indicators of knowledge acquisition are congenital learning, experiential learning, searching new knowledge and grafting external knowledge. The indicators of information distribution include communication, cross training, inter-departmental meetings and social networks. Information interpretation was measured using shared perspective, interpretative frames, unlearning and promptness of interpretation as indicators. Finally, organizational memory indicators include procedures, specialists, skills database and development programs (Sanchez, et al., 2010).

Employees' performance was operationalized based on the indicators advanced in the task and contextual model (Borman and Motowidlo, 1993). The measures adopted to indicate task and contextual performance for this study were service delivery, efficiency, teamwork, citizenship behavior (Dhammika, 2013).

\subsection{Reliability of Research Instrument}

To test the reliability of the research instrument, internal consistency reliability test was conducted on all items to get the Cronbach's alpha coefficient. This approach was considered suitable for measuring internal consistency when multiple Likert questions have been used (Saunders, et al. 2009).

Table 1. Reliability of questionnaire items

\begin{tabular}{lll}
\hline Variables & No. of Items & Cronbach's Alpha Value \\
\hline Organizational Learning & 24 & 0.862 \\
Employees' Performance & 12 & 0814 \\
Organizational Culture & 9 & 0.793 \\
\hline
\end{tabular}

Source: Njoroge, Bula and Wanyoike (2020)

The results presented in table 1 show that the questionnaire had internal consistency with all items having a coefficient value greater than 0.7 as recommended in literature (Hair, et al. 2012).

\section{Results and Discussions}

\subsection{Correlation between Organizational Learning and Employees' Performance}

The study sought to determine whether organizational learning constructs had a correlation with employees' 
performance. A Pearson's correlations of dimensions were conducted to determine correlation coefficients of each variable and employees' performance and to establish whether the correlations were statistically significant using 2 -tailed, sig. $<0.05$. The results revealed statistically significant positive correlations: information distribution has the highest positive correlation, $\mathrm{r}=0.785^{* *}, p(.000)<0.01$, knowledge acquisition, $\mathrm{r}=0.785^{* *} p(.001)<0.01$, organizational memory, $\mathrm{r}=0.712, \mathrm{p}(.017)<0.05$ and information interpretation, $\mathrm{r}=0.549, p(.017)<0.05$.

Hypothesis:

$\mathrm{Ho}_{1:}$ There is no relationship between organizational learning and employees' performance in classified hospitality firms in Kenya

The null hypothesis was rejected since organizational learning constructs had statistically significantly positive correlation with employees' performance, $p$ value was less than 0.05 at $95 \%$ confidence level. These findings imply that there is positive linear relationship between organizational learning and employees' performance. This is consistent with past studies that have established a correlation between organizational learning indicators and employees' performance (Akpotu \& Lebari, 2014).

\subsection{Effect of Organizational Learning and Employees' Performance}

The results of regression analysis revealed that organizational learning predicts employees' performance, $\mathrm{r}^{2}=0.312$, which implies that the organizational learning variables (knowledge acquisition, information distribution, information interpretation and organizational memory) collectively explain 31.2 per cent of the variation in employees' performance. The results of ANOVA test, sig. $\mathrm{p}(0.00)<0.05$ which indicated that the regression model for organizational learning statistically significantly predicted employees' performance. The regression coefficients for knowledge acquisition, $\beta=0.252$, information distribution, $\beta=0287$, information interpretation, $\beta=0.123$, and organizational memory, $\beta=0.197$, $p$ - values $(0.00)<0.05$, indicated that the variables significantly predicted employees' performance. The regression model is $\mathrm{Y}=2.968+0.252 \mathrm{X}_{1}+0.287 \mathrm{X}_{2}+0.113 \mathrm{X}_{3}+0.197$ $\mathrm{X}_{4}$.

Hypothesis :

$\mathrm{Ho}_{2}$ : organizational learning has no effect on employees' performance in classified hospitality firms in Kenya.

The null hypothesis, organizational learning has no effect on employees' performance in classified hospitality firms in Kenya, was rejected since all the four constructs of organizational learning significantly predicted employees' performance at $95 \%$ confidence level. These findings are consistent with empirical literature that have established that organization learning predicts employees' performance (Lee \& Huang, 2012).

\subsection{Moderation Effect of Organizational Culture}

Using multiple regression analysis, test for moderation involved first determining whether there was an overall relationship between organizational learning and employees' performance to moderate.

Table 2. Coefficients for Organizational Learning and Employees' Performance

\begin{tabular}{|c|c|c|c|c|c|}
\hline \multirow[b]{2}{*}{ Model } & \multicolumn{2}{|c|}{ Unstandardized coefficients } & \multicolumn{3}{|l|}{ Standardized coefficients } \\
\hline & $\mathrm{B}$ & Std. Error & Beta & $\mathrm{t}$ & Sig. \\
\hline $1 \quad$ (Constant) & 1.648 & .493 & & 3.343 & .000 \\
\hline Organizational learning & .386 & .077 & .429 & 5.012 & .000 \\
\hline
\end{tabular}

Dependent Variable: employees' performance

Source: Njoroge, Bula and Wanyoike (2020)

The results indicated that there was an effect to moderate, intercept, $\beta_{0}=1.648, p(0.00)<0.05$; organizational learning, $\beta_{11}=0.386, p(0.00)<0.05$ as shown in table 3 
Table 3. Coefficients of moderation analysis

\begin{tabular}{|c|c|c|c|c|c|c|}
\hline \multirow[t]{2}{*}{ Mode } & & \multicolumn{2}{|c|}{ Unstandardized coefficients } & \multirow{2}{*}{$\begin{array}{l}\text { Standardized } \\
\text { coefficients } \\
\text { Beta }\end{array}$} & \multirow[t]{2}{*}{$\mathrm{t}$} & \multirow[t]{2}{*}{ Sig. } \\
\hline & & $\mathrm{B}$ & Std. Error & & & \\
\hline \multirow[t]{3}{*}{1} & (Constant) & 15.733 & 2.147 & & 7.328 & .000 \\
\hline & Organizational learning & .087 & .025 & .387 & 3.480 & .000 \\
\hline & Organizational Culture & 11.269 & 1.216 & .936 & 9.267 & .000 \\
\hline \multirow[t]{4}{*}{2} & (Constant) & 19.365 & 1.972 & & 9.820 & .000 \\
\hline & Organizational learning & .034 & .021 & .244 & 1.619 & .199 \\
\hline & Organizational Culture & 7.506 & 1.685 & .478 & 4.455 & .000 \\
\hline & $\mathrm{OL}^{*} \mathrm{OC}$ & .067 & .014 & .516 & 4.786 & .000 \\
\hline
\end{tabular}

Dependent Variable: employees' performance

Source: Njoroge, Bula and Wanyoike (2020)

The results in table 3 show organizational learning, $\beta=0.034, p(0.199)>0.05$ which implied that organizational learning was a predictor of employees' performance, organizational culture, $\beta=7.506, p(0.000)<0.05$, which implied that organizational culture was not a predictor variable but a moderator variable. The coefficient for the interaction term, $\beta=0.067, p(0.000)<0.05$ indicates that organizational culture has moderator effect on the relationship between organizational learning and employees' performance with a total effect of 0.067 .

Hypothesis for moderation:

$\mathrm{H}_{03}$ : Organizational culture has no moderation effect on the relationship between organizational learning and employees' performance.

The proposed null hypothesis that organizational culture has no moderation effect on the relationship between organizational learning and employees' performance was rejected since the coefficient for the interaction term, $\beta$ $=0.067, \mathrm{p}(0.000)<0.05$ indicates that organizational culture has moderator effect on the relationship between organizational learning and employees' performance with a total effect of 0.067 at $95 \%$ confidence level. These findings are consistent with past studies found moderation effect of organizational learning on the relationship between organizational learning and employees' performance (Erkutlu, 2011; Emeka \& Philemon, 2012; Nazir \& Zamir, 2015).

\section{Conclusions}

The results of this study provide evidence that there is positive correlation and predictive influence between organizational learning and employees' performance. It is evident that knowledge acquisition, information distribution, information interpretation and organizational memory are critical drivers of employees' performance. This implies that adoption of measures used for organizational learning is critical to improvement of employees' performance in terms of service delivery, efficiency, teamwork and citizenship behaviour. This echoes empirical literature that view organizational learning as a panacea for high performance in the service industry (Wallace, et al., 2013.

Further the study establishes that organizational culture has a moderating effect on the linkage between organizational learning and employees' performance. Organizational culture dimensions of innovation and risk taking, outcome orientation and people orientation are significant in creating a context for learning and performance at employee level. Therefore, a culture model that creates an environment supportive of learning process, acquiring of new knowledge, experiential learning, exploitation of existing knowledge through experimentation, knowledge sharing and information distribution, communication networks and organizational memory ultimately positively impacts on employees' behavioural outcomes.

\section{Suggestion for Future Research}

This study provided empirical evidence of the moderating effect of organizational culture on the relationship between organizational learning and employees' performance using Baron and Judge (2013) model of organizational culture. The organizational culture dimensions considered for this study were innovation and risk taking, outcome orientation and people orientation. A future research could consider the other four dimensions, that is, attention to detail, team orientation, aggressiveness and stability, in order to have a broader assessment of organizational culture and establish combination of dimensions that have greater influence on employees' performance. 


\section{References}

Afaneh, J. A., Khaireddin, M. A., Sanjuq, G. M., \& Qaddoumi, J. B. (2014) Impact of Cultural Dimensions According to Hofstede Model on Organizational Commitment of the Middle Management at Jordanian Private Universities. European Journal of Business and Social Sciences, 3(9), 129-146.

Ajayi, O. M., Odusanya, K., \& Morton, S. (2017). Stimulating employee ambidexterity and employee engagement in SMEs. Management Decision, 55(4), 662-680.

Akpotu, C., \& Lebari, E. D. (2014). Knowledge Acquisition and Administrative Employee Performance in Nigerian Universities. Journal of Management and Sustainability, 4(4), 116-124.

Anwar, R., \& Niode, S. (2017). The effects of Learning Organization towards Employees' Innovative Behavior Mediated by Work Engagement (A Study in Indonesia). Advances in Intelligent Systems Research, 131, 159164.

Appelbaum, E., Bailey, T., Berg, P., \& Kalleberg, A. L. (2000). Manufacturing Advantage: Why High-performance Work Systems Pay-off. London: Cornell University Press.

Argote, L. (2011). Organizational learning research: Past, present and future. Management Learning, 42(4), 439446.

Argote, L., \& Spektor, M.L. (2011). Organizational Learning: From Experience to Knowledge. Organization Science, 22(5), 1123-1137.

Argyris, C., \& Schon, D. A. (1996). Organizational Learning: A theory of action perspective. Reading, MA, Addison Wesley.

Bajpai, N. (2011). Business Research Methods. India, Pearson Education.

Bandura A. (2001). Social cognitive theory: An agentic perspective. Annual Review of Psychology, 52, 1-26.

Bandura, A. (1997). Self-Efficacy: The Exercise of Control. New York: W .H. Freeman and Company.

Bandura, A. (2005). Evolution of social cognitive theory. In: Smith K.G. and Hitt M.A. (Eds.). Great minds in management (pp. 9-35). Oxford: Oxford University Press.

Baron, R. M., \& Kenny, D. A. (1986). The moderator-mediator variable distinction in social psychological research: Conceptual, strategic, and statistical considerations. Journal of Personality and Social Psychology, 51(6), 1173-1182.

Borman, W. C., \& Motowidlo, S. J. (1993). Expanding the criterion domain to include elements of contextual performance. In N. Schmitt, \& W. C. Borman (Eds.), Personnel Selection in Organizations (pp. 71-98). San Francisco: Jossey-Bass.

Cameron, K. S., \& Quinn, R. E. (1999). Diagnosing and changing organizational culture based on the competing values framework. Addison-Wesley Publishing.

Caniëls, M., \& Veld, M. (2016). Employee ambidexterity, high performance work systems and innovative work behaviour: How much balance do we need? The International Journal of Human Resource Management. https://doi.org/10.1080/09585192.2016.1216881

Dhammika, K. (2013). Measuring Employees' Performance in the Public Sector in Sri Lanka: Testing of Two Models. Kelaniya Journal of Human Resource Management, 8(1), 1-21.

Easterby-Smith, M., \& Lyles, M. (2011). Handbook of Organizational Learning and Knowledge Management. (2nd ed.). Chichester: Wiley.

Ekore, J. O. (2014). Impact of Key Organizational Factors on Knowledge Transfer Success in Multi-National Enterprises. Management, 19(2), 3-18.

Emeka, N., \& Philemon, A. (2012). The impact of organizational culture on employee performance a study of selected manufacturing industry in Enugu. Asian Journal of Business Management Studies, 3(2), 13-19.

Erkutlu, H. (2011). The moderating role of organizational culture in the relationship between organizational justice and organizational citizenship behaviours. Leadership \& Organization Development Journal, 32(6), 532-554.

Fletcher, M., \& Prashantham, S. (2011). Knowledge assimilation processes of rapidly internationalizing firms: Longitudinal case studies of Scottish SMEs. Journal of Small Business and Enterprise Development, 18(3), 475-501.

Gelard, P., \& Mirsalehi, S. P. (2010). The Relation between Organizational Learning Capability and Product 
Innovation Performance: An Empirical Test in Iranian Organizations. Paper presented at European Conference on Innovation and Entrepreneurship.

Gomes, G., \& Wojahn, R. M. (2016). Management Organizational learning capability, innovation and performance: study in small and medium-sized enterprises (SMES).

Hair. J. F. Jr., Anderson, R. E., Tatham, R. L., \& Black, W. C. (2012). Multivariate Data Analysis with Readings. New Jersey, Englewood Clifts, NJ: Prentice Hall

Hofstede, G. (1997). Cultures and Organizations: Software of the Mind. London: McGraw-Hill.

Hogan, S. J., \& Coote, L. V. (2014). Organizational culture, innovation, and performance: A test of Schein's model. Journal of Business Research, 67, 1609-1621.

Huber, G. P. (1991). Organizational Learning: The Contributing Processes and the Literatures. Organization Science, 20(1), 88-115.

Isa, M. F. M., Ugheoke, S. O., \& Noor, W. S. W. M. (2016). The influence of organizational culture on employees' performance: evidence from Oman. Journal of Entrepreneurship and Business, 4(2), 1-12.

Jong, J. P., \& Hartog, D. N. (2007). How leaders influence employees' innovative behaviour. European Journal of Innovation Management, 10(1), 41- 64.

Kang, S. C., \& Snell, S. A. (2009). Intellectual capital architectures and ambidextrous learning: A framework for human resource management. Journal of Management Studies, 46, 65-92.

Katou, A., \& Budhwar, P. (2010). Casual Relationship between HRM Policies and Organizational Performance: Evidence from the Greek Manufacturing Sector. European Management Journal, 28, 25-39.

Kenya National Bureau of Statistics (KNBS). (2017). Economic Survey 2017.

Lee, C., \& Huang, Y. (2012). Knowledge stock, ambidextrous learning, and firm performance: Evidence from technologically intensive industries. Management Decision, 50(6), 1096-1116.

Li, X., \& Zheng, Y. (2014). The Influential Factors of Employees' Innovative Behavior and the Management Advices. Journal of Service Science and Management, 7, 446-450

Li, Y., Zhang, C., Liu, Y., \& Li, M. (2010). Organizational learning, internal control mechanisms, and indigenous innovation: the evidence from China. IEEE Transactions on Engineering Management, 57(1), 63-77.

Lian, X., Yang, B. Y., \& Ma, Y. T. (2013). The Study of Organizational Innovation Climate Influence on Employee Innovative Behavior. Journal of Management (CHINA), 7, 985-992.

Lin, H., \& Lee, Y. (2017). A Study of the Influence of Organizational Learning on Employees' Innovative Behavior and Work Engagement by a Cross-Level Examination. Journal of Mathematics Science and Technology Education, 13(7), 3463-3478.

Macky, K., \& Boxall, P. (2007). The relationship between high performance work practices and employee attitudes: An investigation of additive and interaction effects. International Journal of Human Resource Management, $18,537-567$.

Nazir \& Zamir. (2015). Impact of Organizational Culture on Employee's Performance. Industrial Engineering Letters, 5(9).

Richards, G. S., \& Duxbery, L. (2014) Work-Group Knowledge Acquisition in Knowledge Intensive Public-Sector Organizations: An Exploratory Study. Journal of Public Administration Research and Theory, 25(4).

Robbins, S. P. (2003). Organisational behaviour (10th ed.). San Diego: Prentice Hall.

Robbins, S. P., \& Judge, T. A. (2013). Organisational Behavior (15th ed.). Pearson, Boston.

Sánchez, J. A., Vijande, M. L., \& Gutiérrez, J. A. (2010). Organisational learning and value creation in business markets. European Journal of Marketing, 44(11/12), 1612-1641.

Saunders, M., Lewis, P., \& Thornhill, A. (2009). Research Methods for Business Students (5th ed.). England: Pearson Education Limited, Edinburgh.

Schein, E. H. (1995). Organizational culture. Campus Verlag. Frankfurt/New York.

Schein, E. H. (2010). Organizational Culture and Leadership (4th ed.). San Francisco, Wiley \& Sons.

Scott, B. B. (2011). Organizational Learning: A Literature Review. IRC Research program, Queen's University IRC. 
Senge, P (1990). The Fifth Discipline: The art and practice of the learning organization. London: Doubleday.

Sola, O. A., \& Ayobami, A. P. (2013). Strategic Impact of Knowledge Management and Organizational Learning on the Perceived Performance of Selected Banks in Oyo State of Nigeria. Journal of Economics and Sustainable Development, 4(2), 45-54.

Tourism Regulatory Authority. (2019).

Wallace, J., Butts, M., Johnson, P., Stevens, F., \& Smith, M. (2013). A multilevel model of employee innovation understanding the effects of regulatory focus, thriving, and employee involvement climate. Journal of Management, 1-23.

Whisman, M. A., \& McClelland, G. H. (2005). Designing, Testing, and Interpreting Interactions and Moderator Effects in Family Research. Journal of Family Psychology, 19(1), 111-120.

Zaitseva, N. A. (2013). Management in Service Industry: Tourism and Hospitality. Moscow, Academia Publishing House.

Zhang, Y., \& Li, S. (2009). High Performance Work Practices and Firm Performance: Evidence from the Pharmaceutical Industry in China. The International Journal of Human Resource Management, 20(11), 23312348 .

Zheng, W., Yang, B., \& McLean, G. (2010). Linking organizational culture, structure, strategy, and organizational effectiveness: Mediating role of knowledge management. Journal of Business Research, 63, 763-771.

Zhou, C. Z., \& Wu, F. (2010). Technological capability, strategic flexibility, and product innovation. Strategic Management Journal, 31(5), 547-561.

\section{Copyrights}

Copyright for this article is retained by the author(s), with first publication rights granted to the journal.

This is an open-access article distributed under the terms and conditions of the Creative Commons Attribution license (http://creativecommons.org/licenses/by/4.0/). 